\title{
On the mechanism of the antidepressant-like action of group II mGlu receptor antagonist, MGS0039
}

\author{
Agnieszka Pałucha-Poniewiera • \\ Joanna M. Wierońska • Piotr Brański • \\ Katarzyna Stachowicz • Shigeyuki Chaki • Andrzej Pilc
}

Received: 31 March 2010/Accepted: 25 July 2010 /Published online: 12 August 2010

(C) The Author(s) 2010. This article is published with open access at Springerlink.com

\begin{abstract}
Rationale Several studies have suggested that modulation of the glutamatergic system could be a new, efficient way to achieve antidepressant activity. Behavioral data showed that group II mGlu receptor antagonists (i.e., $(1 R, 2 R, 3 R, 5 R$, 6R)-2-amino-3-(3,4-dichlorobenzyloxy)-6-fluorobicyclo [3.1.0]hexane-2,6-dicarboxylic acid (MGS0039) and (2S)-2-amino-2-[(1S,2S)-2-carboxycycloprop-1-yl]-3-(xan th-9-yl) propanoic acid (LY341495)) elicited antidepressant activity in several animal models of depression in rats and/or mice. Although the antidepressant-like activity of MGS0039 and LY341495 is well documented, the mechanism of the antidepressant action of these compounds is still not clear. Objectives The aim of the present study was to specify the role of the serotonergic system in the mechanism of the antidepressant-like activity of group II mGlu receptor ligands by using the tail suspension test (TST) in mice; the role of AMPA receptors was also investigated. Furthermore, the possible antidepressant-like action of
\end{abstract}

A. Pałucha-Poniewiera $(\bowtie) \cdot J$. M. Wierońska $\cdot$ P. Brański

K. Stachowicz $\cdot$ A. Pilc

Department of Neurobiology,

Institute of Pharmacology Polish Academy of Sciences,

Smętna 12 ,

31-343 Kraków, Poland

e-mail: nfpaluch@cyf-kr.edu.pl

S. Chaki

Discovery Pharmacology, Molecular Function and Pharmacology

Laboratories, Taisho Pharmaceutical Co., Ltd,

1-403 Yoshino-cho, Kita-ku,

Saitama 331-9530, Japan

A. Pilc

Collegium Medicum, Faculty of Health Sciences,

Jagiellonian University,

Kraków, Poland
MGS0039 using the olfactory bulbectomy (OB) model of depression in rats was investigated.

Results The results of the TST studies showed that antidepressant-like action of group II mGlu receptor antagonists does not depend on serotonergic system activation. However, the AMPA receptor seems to play a key role in the antidepressant-like action of these compounds. Moreover, we have shown that repeated administration of MGS0039 attenuated OB-related deficits, confirming antidepressant-like activity of the tested compound.

Conclusions The results suggest that the blockade of group II mGlu receptors may be effective in the treatment of depression. Moreover, we have found that the mechanism of action of group II mGlu receptor antagonists differs from that of typical antidepressants, such as SSRIs.

Keywords AMPA receptors - Antidepressant drugs · Group II mGlu receptors · Forced swim test · Locomotor activity - LY341495 - MGS0039 - Olfactory bulbectomy . Serotonergic receptors · Tail suspension test

\section{Introduction}

Preclinical data has indicated that modulating the glutamatergic system might be an alternative, efficient method to achieve an antidepressant effect (Pałucha and Pilc 2007; Pilc et al. 2008; Skolnick et al. 2009; Wierońska and Pilc 2009). Two types of glutamatergic receptors are responsible for the regulation of glutamatergic neurotransmission: ionotropic glutamate receptors (iGlu receptors), including NMDA, AMPA, a kainate receptors, and metabotropic glutamate receptors (mGlu receptors) composed of eight mGlu receptor subtypes (mGlu1-mGlu8 receptors), divided into three groups: group I (mGlu1 and mGlu5 receptors), 
group II (mGlu2 and mGlu3 receptors), and group III containing mGlu4, mGlu6, mGlu7, and mGlu8 receptors (Conn and Pin 1997). Some data collected from the last few years have indicated that ligands of mGlu receptors, particularly antagonists of mGlu5 receptors and antagonists of group II mGlu receptors, produced antidepressant-like effects in rodent models of depression (Pałucha and Pilc 2007).

Among group II mGlu receptor ligands, MGS0039 (Chaki et al. 2004) and LY341495 (Ornstein et al. 1998) have been best characterized as potential antidepressants. Behavioral studies showed that both compounds elicited antidepressant activity in the tail suspension test (TST), in the rat forced swim test (FST) (Chaki et al. 2004), and the learned helplessness paradigm in rats (Yoshimizu et al. 2006). Furthermore, MGS0039 has been reported to increase cell proliferation in the adult mouse hippocampus after 2 weeks administration (Yoshimizu and Chaki 2004). It is proposed that neurogenesis is related to the mechanism of action of antidepressant drugs, and the behavioral effects of antidepressants were shown to be correlated with the stimulation of neurogenesis in the adult hippocampus (Santarelli et al. 2003). Thus, the MGS0039-promoted proliferation of hippocampal neurons may be additional evidence for the support of antidepressant-like activity of group II mGlu receptor antagonists.

Although the antidepressant activity of MGS0039 and LY341495 is well documented, the mechanism of the antidepressant action of these compounds is still not clear.

Some data has indicated that the mechanism of the antidepressant-like activity of group II mGlu receptor antagonists might be related to serotonergic system regulation. Firstly, it was shown that the application of mGlu2/3 receptor antagonists stimulated the activity of serotonergic neurons in the dorsal raphe nucleus and increased extracellular concentration of serotonin in the medial prefrontal cortex in freely moving rats (Karasawa et al. 2005; Kawashima et al. 2005). Therefore, the activation of serotonergic neurotransmissions may be responsible for the antidepressant-like activity of group II mGlu receptor antagonists. Secondly, when a modified version of the FST was used to determine the antidepressant-like profile of MGS0039 and LY341495 in rats, i.e., three parameters were measured (climbing, swimming, and immobility), both compounds induced an increase in swimming behavior and a decrease in immobility without affecting the climbing behavior, similar to a reference antidepressant drug, fluvoxamine (Chaki et al. 2004). Such a pattern of activity in the FST suggests serotonin-dependent mechanism of antidepressant-like activity of mGlu2/3 receptor antagonists (Detke et al. 1995).

Furthermore, pretreatment with AMPA receptor antagonist, NBQX (2,3-dioxo-6-nitro-1,2,3,4-tetrahydrobenzo[f] quinoxaline-7-sulfonamide), attenuated the increase in serotonin release by MGS0039 in the rats' medial prefrontal cortex, and, on the other hand, NBQX prevented the antidepressant-like effect of MGS0039 in the TST. Therefore, it seems that AMPA receptors played a role in the mechanism of action of MGS0039 in the TST (Karasawa et al. 2005).

Thus, we decided to assess the role of the serotonergic system in the mechanism of antidepressant-like activity of group II mGlu receptor ligands and to investigate other possible mechanisms responsible for the antidepressant-like action of MGS0039 and LY341495, including the involvement of AMPA receptors, by using the TST in mice.

Furthermore, the possible antidepressant-like action of MGS0039 using the olfactory bulbectomy (OB) model of depression in rats was investigated. The $\mathrm{OB}$ model of depression has been previously used to assess a series of novel potential antidepressant drugs, including those acting via the glutamatergic system, such as the NMDA receptor antagonist, dizocilpine (Redmond et al. 1997) or mGlu5 receptor antagonists such as MTEP or MPEP (Pałucha et al. 2005; Pilc et al. 2002) or GABAB receptor antagonists (Nowak et al. 2006). Therefore, it seems that the OB model of depression appears to be useful to also investigate the antidepressant-like effects of the group II mGlu receptor antagonist.

\section{Materials and methods}

Animals and housing

Male Sprague-Dawley rats (Charles River, Germany), weighing $250-270 \mathrm{~g}$, were used to assess antidepressantlike effects in the OB model of depression, while male C57BL/6J mice (IF PAN breeding facility), weighing 23$25 \mathrm{~g}$, were used in the TST. The animals were kept under standard laboratory conditions of lighting (light phase 7:00-19:00) and temperature $\left(19-21^{\circ} \mathrm{C}\right)$. Food and water were freely available. Each experimental group consisted of seven to nine animals. All the subjects were experimentally naive and used only once in each test, apart from the OB rats, which were used in the open field test and 2 days later in the passive avoidance test. Experiments were performed during the light period (9:00-14:00 h) by an observer unaware of the treatment. All procedures were conducted according to the guidelines of the National Institutes of Health Animal Care and Use Committee and were approved by the Ethics Committee of the Institute of Pharmacology, Polish Academy of Sciences in Kraków.

Drug administration

MGS0039 (Taisho Pharmaceutical Co., Ltd., Saitama, Japan), LY341495 (Tocris Cookson Ltd., Bristol, UK), ritanserin 
(Tocris Cookson Ltd., Bristol, UK), metergoline (Tocris Cookson Ltd., Bristol, UK), and para-chlorophenylalanine (PCPA) (Sigma-Aldrich, St. Louis, USA) were dispersed in a suspension of $0.5 \%$ methylcellulose, which was used as a vehicle. WAY100635 (N-\{2-\{4-(2-methoxyphenyl)-1piperazinyl ethyl $\}-N$-(2-pyridinyl) cyclo-hexanecarboxamide fumarate) (Sigma-Aldrich, St. Louis, USA) and NBQX disodium salt (Ascent scientific Ltd., Bristol, UK) were dissolved in sterile water. Amitriptyline (Sigma-Aldrich, St. Louis, USA) was soluble in $0.9 \%$ $\mathrm{NaCl}$. In mice, MGS0039 and LY341495 were administered intraperitoneally (IP) $30 \mathrm{~min}$ before the test. Metergoline and ritanserin were given IP, $60 \mathrm{~min}$ before the experiment. WAY 100635 and NBQX were administered subcutaneously (SC), 45 and $35 \mathrm{~min}$, respectively, before the test. In the OB studies in rats, the administration of the drugs began 2 weeks after surgery. Amitriptyline (10 mg/kg, IP) and MGS0039 (1 and $3 \mathrm{mg} / \mathrm{kg}$, IP) were given for 14 days, once daily, between 8:00 and 10:00 a.m., $24 \mathrm{~h}$ after the last dose open field test was done. Drugs were administered after the test and the day after. The passive avoidance test was performed 2 days after the open field test, $24 \mathrm{~h}$ after the drugs' administration.

\section{Olfactory bulbectomy}

\section{Surgical procedure}

Using our published standard procedure (Pałucha et al. 2005; Wierońska et al. 2002) the following, to summarize it here only briefly, was done: 1 week after arrival in the laboratory, a bilateral olfactory bulbectomy was performed on rats under a ketamine $(100 \mathrm{mg} / \mathrm{kg}) / x y l a z i n e ~(10 \mathrm{mg} / \mathrm{kg})$ anesthesia. Metoxicam $(0.05 \mathrm{mg} / \mathrm{kg}, \mathrm{SC})$ was given as an analgesic and anti-inflammatory drug $60 \mathrm{~min}$ both before the operation and the following 2 days after the surgery. Following exposure of the skull, burr holes were drilled using the coordinates $7 \mathrm{~mm}$ anterior to the bregma and $2 \mathrm{~mm}$ (on either side) from the middle line, i.e., at a point corresponding to the posterior margin of the orbit of the eye. The olfactory bulbs were removed by suction, and the burr holes were filled with a haemostatic sponge (Ferrosan, Poland). The skin was closed. Sham-operated animals were similarly treated, but the bulbs were left intact. The animals were allowed to recover for 14 days following surgery; they were handled daily by the experimenter throughout the recovery period to eliminate any aggressiveness that would otherwise develop (Leonard and Tuite 1981).

\section{Open field}

The open field test was performed using an "open field" apparatus consisting of an arena $90 \mathrm{~cm}$ in diameter which was divided into $10 \mathrm{~cm}$ squares by faint yellow lines. The field was surrounded by a $75-\mathrm{cm}$ high aluminum sheet. Illumination was provided by a $60-\mathrm{W}$ bulb, which was positioned $90 \mathrm{~cm}$ above the floor. All measurements were carried out in a darkened room. The animals were individually placed in the center of the open field and allowed to freely explore for $3 \mathrm{~min}$. The behaviors of interest were the episodes of rearing, defined as raising the forepaws from the floor, and ambulation, i.e., the number of sector lines crossed (once a line had been crossed with all four paws).

\section{Passive avoidance paradigm}

The passive avoidance test was performed using an open box $(55 \times 35 \times 20 \mathrm{~cm})$ with black walls and a stainless steel grid floor. The rods were 1 and $2 \mathrm{~cm}$ apart and were connected to the terminals of the stimulator delivering a square wave pulse. The delivered shock had a constant intensity $(0.75 \mathrm{~mA})$ and lasted for $1 \mathrm{~s}$. A wooden platform measuring $12 \times 12 \times 3 \mathrm{~cm}$ was positioned in the center of the box onto which each rat was initially placed. Once the rat left the platform with all four paws it received an electric shock. The animals were immediately removed from the experimental cage and transferred to the home cage. The next trial was initiated after a 30 -s interval. The experiment was stopped once the rat had learned to stay on the platform for $1 \mathrm{~min}$.

\section{Lesion verification}

Rats were sacrificed after all experimental procedures had been performed. The brains were rapidly removed and examined for signs of cortical damage or incomplete removal of olfactory bulbs. Such animals were excluded from the data analysis.

\section{Tail suspension test}

Immobility was induced by tail suspension according to the procedure of Steru et al. (1985). C57BL/6J mice were individually suspended by their tails by a plastic string positioned horizontally $75 \mathrm{~cm}$ above the tabletop using adhesive tape placed about $1 \mathrm{~cm}$ from the tip of the tail. The immobility duration was recorded for $6 \mathrm{~min}$. Mice were considered immobile only when they hanged down passively and were completely motionless.

Locomotor activity test in mice

The spontaneous locomotor activity of mice was measured in Plexiglas locomotor activity chambers $(40 \times 20 \times 15 \mathrm{~cm})$ in a 20-station photobeam activity system (Opto-M3 Activity Meter, Columbus Instruments, USA) where the 
animals were placed individually $30 \mathrm{~min}$ after the injection of MGS0039. The total number of ambulations was recorded for $30 \mathrm{~min}$ and stored every $5 \mathrm{~min}$.

\section{HT depletion}

To deplete 5HT, mice were pretreated with the tryptophan hydroxylase inhibitor, PCPA ( $300 \mathrm{mg} / \mathrm{kg})$, which was given $\mathrm{IP}$, at a dose of $300 \mathrm{mg} / \mathrm{kg}$. Injections were made twice daily (at 9:00 a.m. and at 18:00), for three consecutive days. Experiments were made on the fourth day and started at 10:00 a.m.

\section{Statistical analysis}

The data was presented as the means \pm SEM and evaluated by the two-way ANOVA followed by Bonferroni's post hoc test (TST) or the repeated measure ANOVA followed by Dunnett's test (locomotor activity). GraphPad Prism version 4.00 for Windows 2000 (GraphPad Software, San Diego CA, USA) was used to analyze the data.

The results of the $\mathrm{OB}$ experiments were analyzed by factorial ANOVA followed by LSD post hoc comparison with the use of STATISTICA ver. 8.0 software.

\section{Results}

Effects of MGS0039 in the olfactory bulbectomy model of depression

\section{Open field}

The analysis of the results of the ambulation scores with ANOVA revealed a significant group $[F(1,24)=4.47]$, treatment $[F(1,24)=5.5]$, and the group $\times$ treatment interaction in all experimental groups $[F(1,24)=9.12]$ (Fig. 1a).

LSD post hoc analysis showed a significant lesion effect in the vehicle-treated animals $(p<0.00001)$. The significant treatment effect was observed in amitriptyline (AMI)treated groups, where the attenuation of the OB-induced deficit was observed $(p<0.001)$. The analysis that included the two doses of MGS0039 also revealed a significant lesion $\times$ treatment interaction $(p<0.001)$ (Fig. 1a).

The analysis of the results of rearings with ANOVA revealed a significant group $[F(1,24)=17.54]$, treatment $[F$ $(1,23)=23.66]$, and the group $\times$ treatment interaction in all experimental groups $[F(1,24)=2.7]$ (Fig. 1b).

LSD post hoc analysis showed a significant lesion effect in the vehicle-treated animals $(p<0.00001)$. The significant treatment effect was observed in AMI-treated groups, where the attenuation of OB-induced deficit was observed $(p<0.0001)$. In the analysis that included two doses of
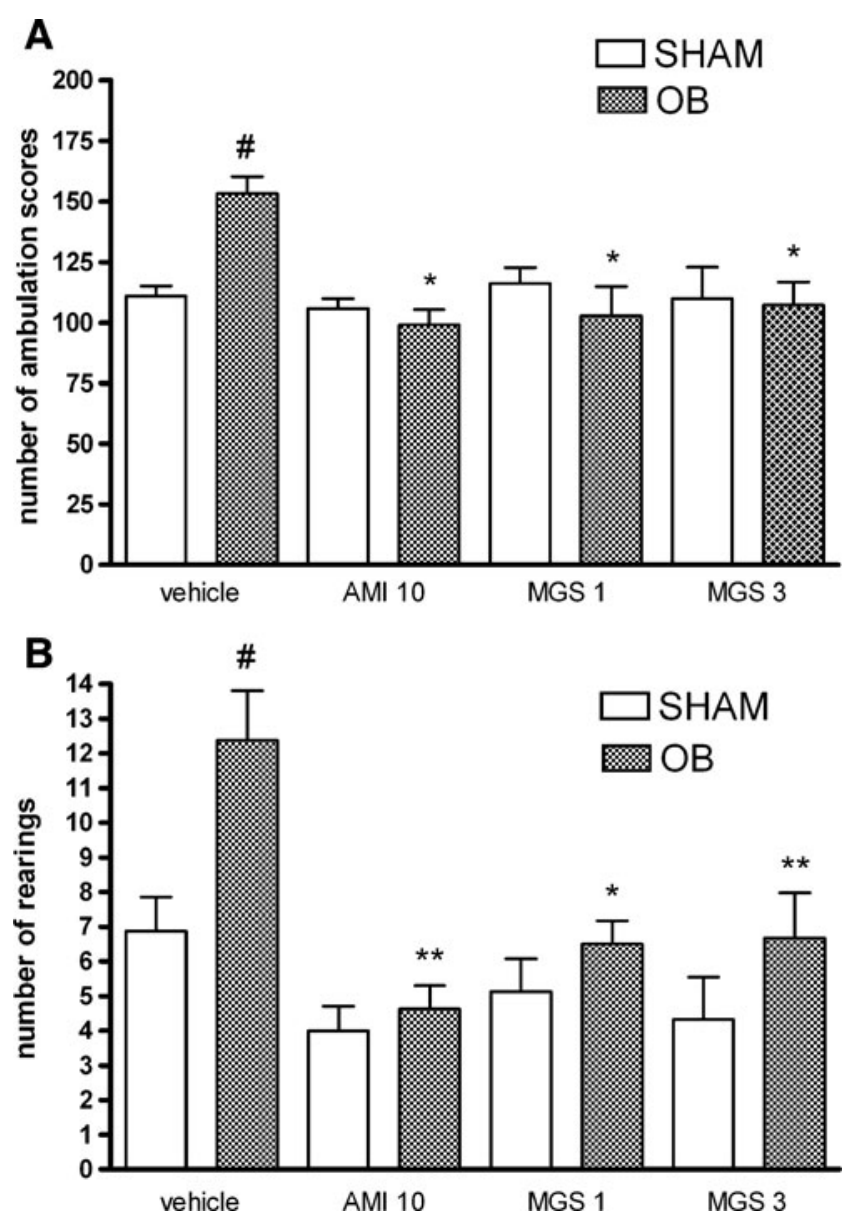

Fig. 1 The effect of amitriptyline (AMI; $10 \mathrm{mg} / \mathrm{kg}$, IP) and MGS0039 ( 1 and $3 \mathrm{mg} / \mathrm{kg}$, IP) on the ambulatory movement (a) and the number of rearings (b) in the OB model of depression. Rats were administrated for 14 days with each compound in each group. At $24 \mathrm{~h}$ following the last treatment, ambulatory scores were measured in the "open field". Data from the session is expressed as mean and SEM and analyzed using two-way ANOVA followed by the Fisher LSD test. $\# p<0.00001$ vs. sham/vehicle group; ${ }^{*} p<0.001,{ }^{* *} p<0.0001$ vs. $\mathrm{OB} /$ vehicle group. Six to seven animals per group were used

MGS0039, it was also revealed that there was a significant lesion $\times$ treatment interaction $(p<0.001$ and $p<0.0001$ for 1 and $3 \mathrm{mg} / \mathrm{kg}$ of MS0039, respectively) (Fig. 1b).

\section{Passive avoidance paradigm}

The analysis of the results of the passive avoidance procedure with two-way ANOVA revealed a significant group $[F(1,24)=22.8]$, treatment $[F(1,24)=24.6]$, and the group $\times$ treatment interaction in all experimental groups $[F(1,24)=28.5]$ (Fig. 2).

LSD post hoc analysis showed a significant lesion effect in the vehicle-treated animals $(p<0.00001)$. The significant treatment effect was observed in AMI-treated groups, where the attenuation of the OB-induced deficit was observed $(p<0.00001)$. In the analysis that included two 


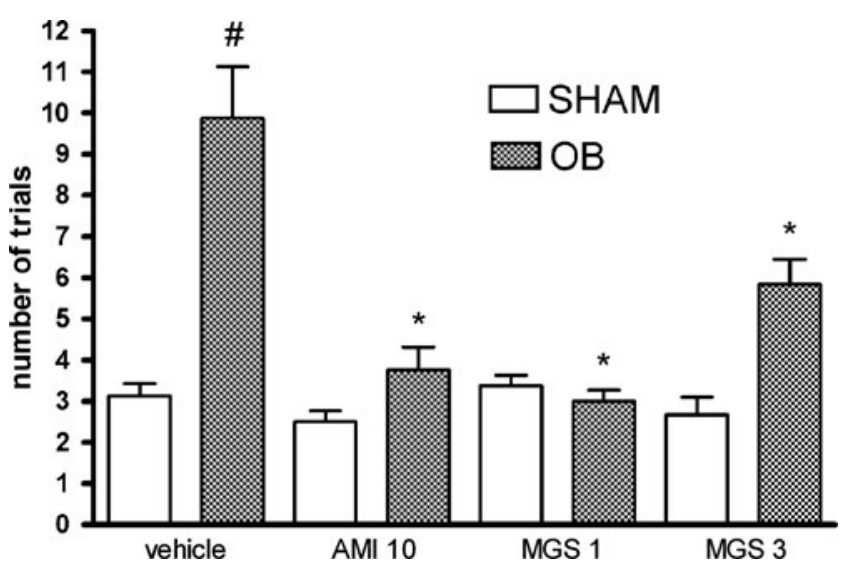

Fig. 2 The effect of amitriptyline (AMI; $10 \mathrm{mg} / \mathrm{kg}$, IP) and MGS0039 ( 1 and $3 \mathrm{mg} / \mathrm{kg}, \mathrm{IP}$ ) in the passive avoidance paradigm in the OB model of depression. Rats were administrated for 14 days with each compound in each group. At $24 \mathrm{~h}$ following the last treatment, the number of scores was measured in the passive avoidance paradigm. Data from the session is expressed as mean and SEM and analyzed using two-way ANOVA followed by the Fisher LSD test. $\# p<0.00001$ vs. sham/vehicle group; ${ }^{*} p<0.00001$ vs. OB control group. Seven animals per group were used

doses of MGS0039, it was also revealed that there was a significant lesion $\times$ treatment interaction $(p<0.00001$ for 1 and $3 \mathrm{mg} / \mathrm{kg}$ ). Moreover, a significant difference between sham and OB animals receiving the MGS0039 in a dose of $3 \mathrm{mg} / \mathrm{kg}$ was observed $(p<0.001)$ (Fig. 2).

Effects of antagonists of 5HT receptors on the antidepressant-like activity of MGS0039 in the TST

MGS0039, administered at a dose of $3 \mathrm{mg} / \mathrm{kg}$, decreased the immobility time of C57BL/6J mice in the TST by about $66 \%$. An antagonist of the 5HT1A receptor, WAY 100635 $(0.1 \mathrm{mg} / \mathrm{kg})$, given alone, did not change the behavior of animals in this test and it did not significantly influence the

Fig. 3 a The effect of WAY $100635(0.1 \mathrm{mg} / \mathrm{kg})$ on the antidepressant-like activity of MGS0039 (3 mg/ $\mathrm{kg})$ in the TST in mice. Mice were pretreated with WAY100635 and with MGS0039, respectively, 45 and $30 \mathrm{~min}$ before the test. Values are expressed as the means \pm SEM and analyzed by two-way ANOVA followed by Bonferroni's post hoc test, ${ }^{* * *} p<0.001$ vs. control group. b The effect of WAY100635 $(0.1 \mathrm{mg} / \mathrm{kg})$ on the antidepressant-like activity of MGS0039 $(0.3 \mathrm{mg} / \mathrm{kg})$ in the TST in mice. Mice were pretreated with WAY 100635 and with MGS0039, respectively, 45 and 30 min before the test. Values are expressed as the means \pm SEM and analyzed by two-way ANOVA followed by Bonferroni's post hoc test. c The effect of ritanserin $(0.5 \mathrm{mg} / \mathrm{kg})$ on the antidepressant-like activity of MGS0039 (3 mg/kg) in the TST in mice. Mice were pretreated with ritanserin and with MGS0039, respectively, 60 and $30 \mathrm{~min}$ before the test. Values are expressed as the means \pm SEM and analyzed by twoway ANOVA followed by Bonferroni's post hoc test, $* * * p<0.001$ vs. control group. Seven animals per group were used antidepressant-like effect of MGS0039 $[F(1,24)=0.07, p=$ 0.7927] (Fig. 3a).

MGS0039 was not active in the TST at a dose of $0.3 \mathrm{mg} / \mathrm{kg}$. Two-way ANOVA revealed that WAY100635 $(0.1 \mathrm{mg} / \mathrm{kg})$ showed the tendency to enhance the non-active dose of MGS0039 $(0.3 \mathrm{mg} / \mathrm{kg})$, although the effect was not statistically significant, $[F(1,24)=2.115, p=0.158]$ (Fig. 3b).

The $5 \mathrm{HT} 2 \mathrm{~A} / 2 \mathrm{C}$ receptor antagonist, ritanserin $(0.5 \mathrm{mg} / \mathrm{kg})$, was not active in the TST when given alone, and it did not

\section{A}

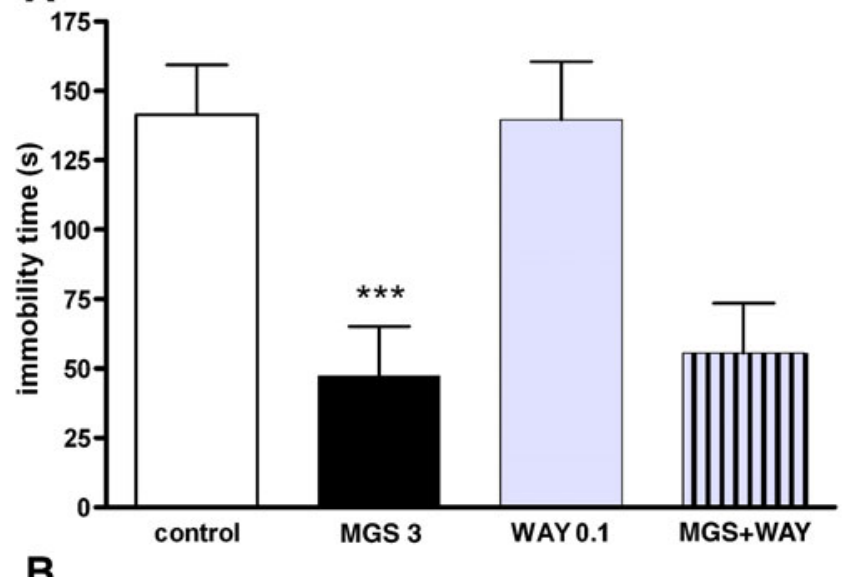

B
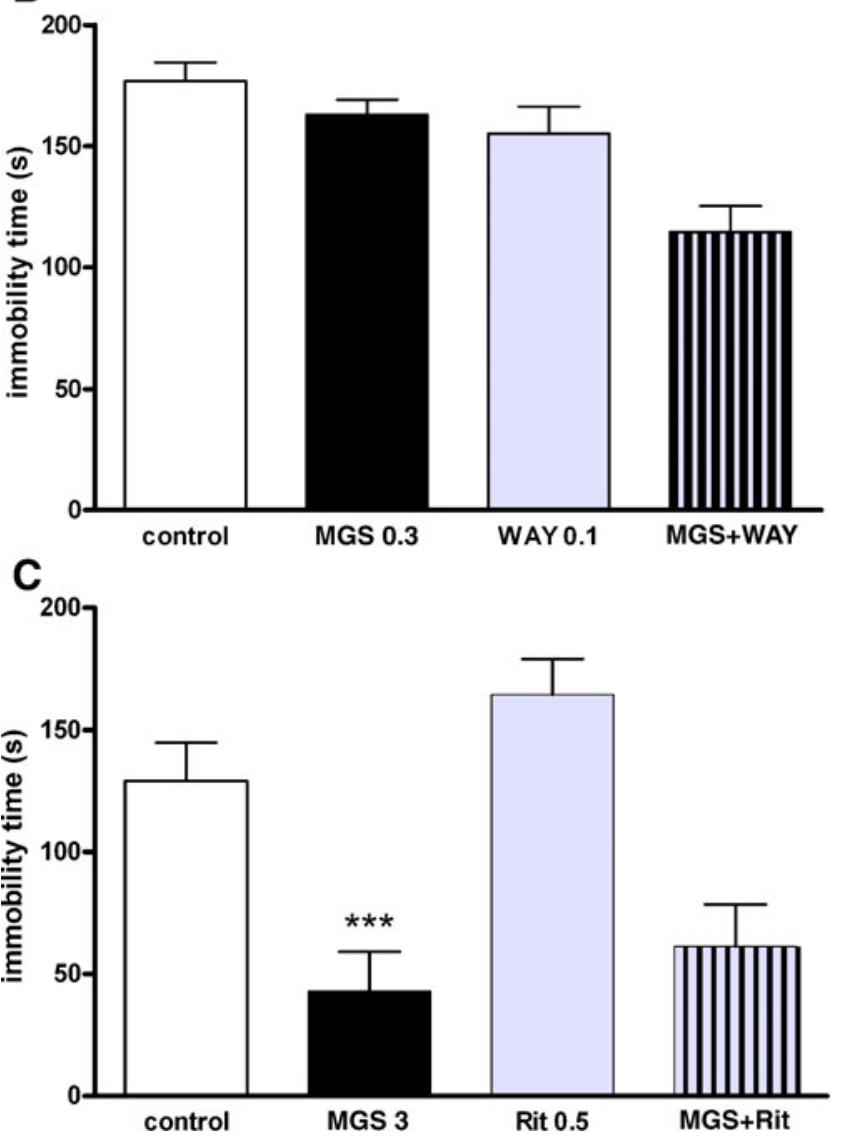
influence the MGS0039 (3 mg/kg)-induced attenuation of immobility time in the TST in mice $[F(1,24)=0.2868, p=$ 0.5972] (Fig. 3c).

Effects of antagonists of 5HT receptors on the antidepressant-like activity of LY341495 in the TST

LY341495, given at a dose of $1 \mathrm{mg} / \mathrm{kg}$ decreased the immobility time of the C57BL/6J mice in the TST by about $70 \%$. An antagonist of the 5HT1A receptor, WAY 100635 $(0.1 \mathrm{mg} / \mathrm{kg})$, given alone, did not change the behavior of the animals in this test, and it did not significantly influence the antidepressant-like effect of LY341495 $[F(1,27)=0.1255, p=$ 0.7259] (Fig. 4a). The 5HT2A/2C receptor antagonist, ritanserin $(0.5 \mathrm{mg} / \mathrm{kg})$, was not active in the TST when given by itself, and it did not influence the LY341495induced attenuation of the immobility time in the TST in mice $[F(1,27)=1.099, p=0.3037]$ (Fig. 4b). Furthermore, the $5 \mathrm{HT}$ antagonist metergoline $(0.5 \mathrm{mg} / \mathrm{kg})$, given by itself, was not active in the TST, and it did not significantly influence the antidepressant-like effect of LY341495 $[F(1,26)=0.3402$, $p=0.5647$ ] (Fig. 4c).

The effect of the AMPA receptor antagonist on the antidepressant-like activity of MGS0039 in the TST

The AMPA receptor antagonist, NBQX, given at a dose of $10 \mathrm{mg} / \mathrm{kg}$ did not change the behavior of mice in the TST, although it antagonized an antidepressant-like effect of MGS0039 given at a dose of $3 \mathrm{mg} / \mathrm{kg}[F(1,24)=5.907, p=$ 0.0229] (Fig. 5).

Effects of serotonin depletion on the antidepressant-like activity of citalopram and MGS0039 in the TST

Pretreatment with PCPA did not alter the baseline immobility of mice. Citalopram, used as a reference drug, at a dose of $20 \mathrm{mg} / \mathrm{kg}$ significantly decreased the immobility time of mice in the TST $[F(1,26)=61.67, p<$ 0.0001]. Two-way ANOVA revealed a significant interaction between pretreatment with PCPA and citalopram administration $[F(1,26)=27.45, p<0.0001]$, showing that citalopram was not active in the TST in the serotonindepleted mice (Fig. 6a).

MGS0039, at a dose of $3 \mathrm{mg} / \mathrm{kg}$, was active in the TST in both control and PCPA-pretreated mice $[F(1,26)=$ $132.4, p<0.0001]$. Two-way ANOVA also showed a significant interaction between pretreatment with PCPA and MGS0039 administration $[F(1,26)=4.477, p<0.0441]$, suggesting that the antidepressant-like activity of MGS0039 in serotonin-depleted mice was increased in comparison to the control group not treated with PCPA (Fig. 6b).

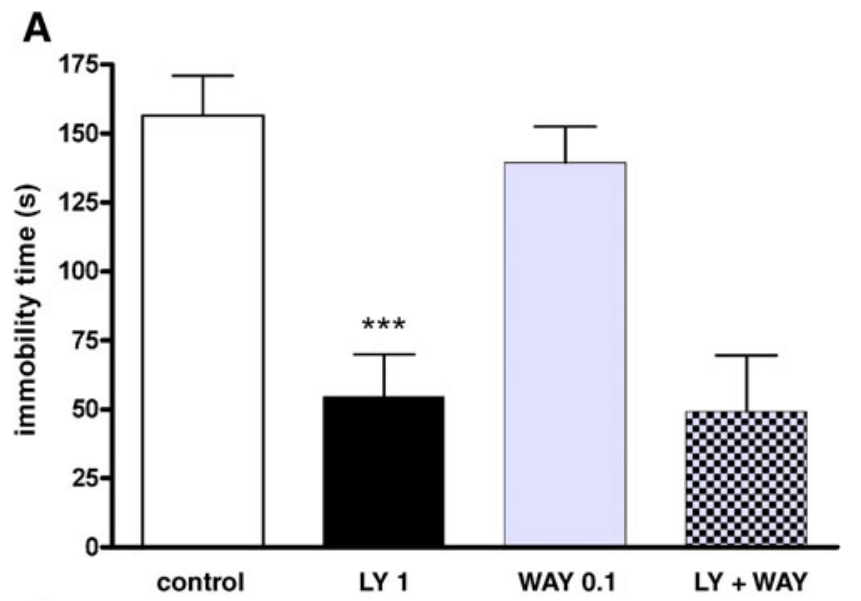

B

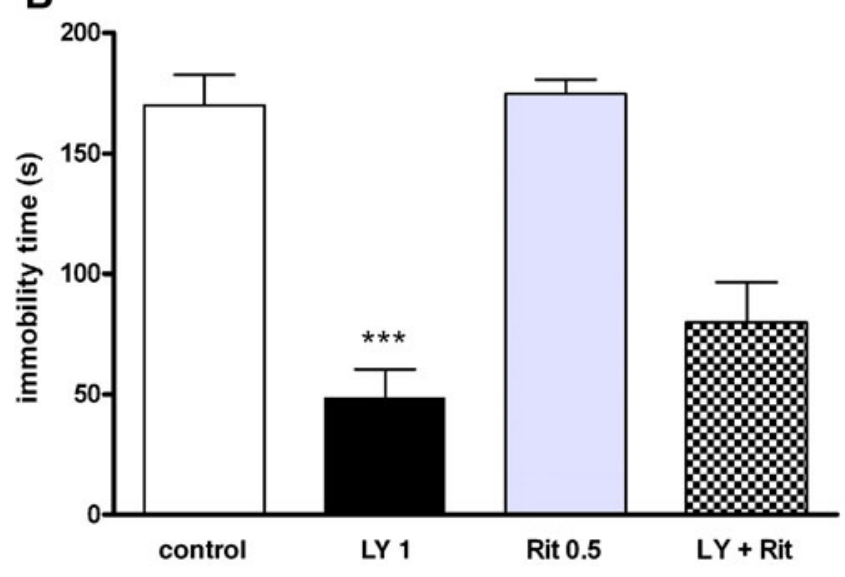

C

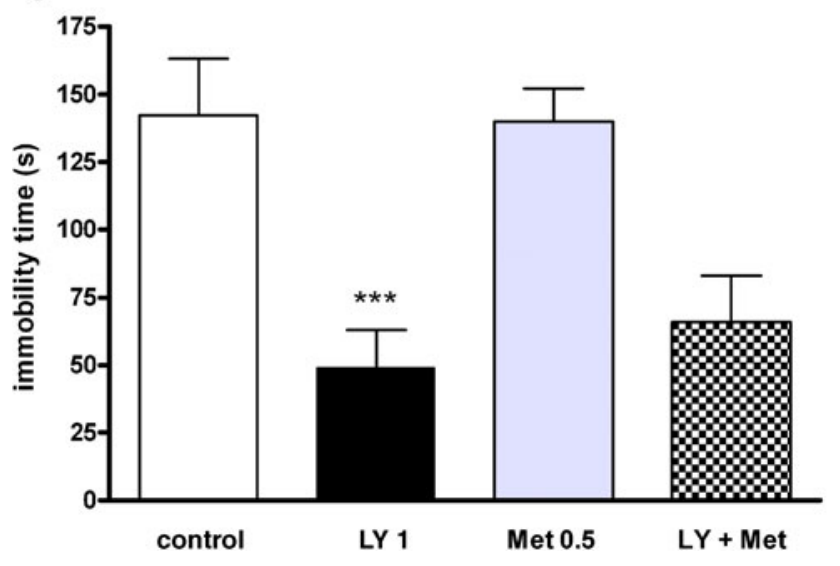

Fig. 4 The effect of WAY100635 (0.1 mg/kg) (Fig. 2a), ritanserin $(0.5 \mathrm{mg} / \mathrm{kg})$ (Fig. 2b), or metergoline $(0.5 \mathrm{mg} / \mathrm{kg})$ (Fig. $2 \mathrm{c})$ on the antidepressant-like activity of LY341495 $(1 \mathrm{mg} / \mathrm{kg})$ in the TST in mice. WAY 100635 was given $45 \mathrm{~min}$, ritanserin $60 \mathrm{~min}$, metergoline $60 \mathrm{~min}$, and LY341495 $30 \mathrm{~min}$ before the test. Values are expressed as the means \pm SEM and analyzed by two-way ANOVA followed by Bonferroni's post hoc test, $* * * p<0.001$ vs. control group. Seven to eight animals per group were used 


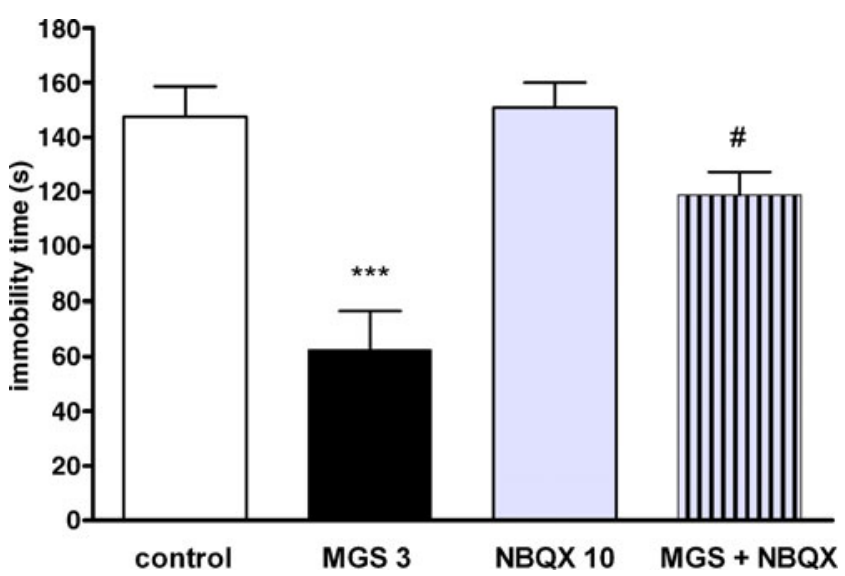

Fig. 5 The effect of NBQX $(10 \mathrm{mg} / \mathrm{kg})$ on the antidepressant-like activity of MGS0039 (3 mg/kg) in the TST in mice. NBQX and MGS0039 were given, respectively, 35 and $30 \mathrm{~min}$ before the test. Values are expressed as the means \pm SEM and analyzed by two-way ANOVA followed by Bonferroni's post hoc test. $* * * p<0.001$ vs. control group, $\# p<0.05$ vs. MGS0039-treated group. Seven animals per group were used

Effect of the AMPA receptor antagonist

on the antidepressant-like activity of MGS0039

in serotonin-depleted mice in the TST

AMPA receptor antagonist, NBQX, given at a dose of $10 \mathrm{mg} / \mathrm{kg}$, did not alter the baseline immobility of PCPApretreated mice. MGS0039, given at a dose of $3 \mathrm{mg} / \mathrm{kg}$, induced an antidepressant-like effect in PCPA-pretreated mice $[F(1,24)=75.14, p<0.0001]$, and this effect was not blocked by NBQX, given at a dose of $10 \mathrm{mg} / \mathrm{kg}[F(1,24)=$ $1.479, p=0.2357$ ] (Fig. 7a). Subsequent experiments confirmed that MGS0039, at a dose of $3 \mathrm{mg} / \mathrm{kg}$, decreased the immobility time in 5HT-depleted animals in the TST. Twoway ANOVA showed that this effect was antagonized by NBQX, administered at a dose of $20 \mathrm{mg} / \mathrm{kg}[F(1,26)=$ 6.853, $p=0.0146]$, which did not change the behavior of mice, when it was given by itself (Fig. 7b).

The effects of antagonists of the 5HT receptors and MGS0039 on the locomotor activity of mice

MGS0039, at a dose of $3 \mathrm{mg} / \mathrm{kg}$, did not induce changes in the locomotor activity of mice $[F(1,60)=0.2384, p=$ $0.6341]$, although a significant effect of time on the parameter $[F(5,60)=61.18, p<0.0001]$ was observed. WAY100635, at a dose of $0.1 \mathrm{mg} / \mathrm{kg}$, did not influence the basal locomotor activity of mice $[F(1,60)=3.337, p=$ 0.0927]. Mice injected with MGS0039 co-administered with WAY100635 were statistically less active in the locomotor activity test than control animals (the curves were significantly different) $[F(1,60)=23.87, p=0.0004]$. Post hoc analysis revealed that MGS0039+WAY100635 decreased basal locomotor activity at the first time point of 5 min $(p<0.05)$, suggesting decreased exploratory activity. Furthermore, there was a significant influence of MGS0039 on the locomotor activity of WAY100635-treated animals (curves "WAY100635" and "WAY100635+MGS0039" were significantly different) $[F(1,60)=15.82, p=0.0018]$ (Fig. 8a).

When WAY100635 $(0.1 \mathrm{mg} / \mathrm{kg})$ was co-administered with a lower dose of MGS0039 $(0.3 \mathrm{mg} / \mathrm{kg})$, no changes in locomotor activity were observed compared to the control group (Fig. 8b).

Ritanserin, given at a dose of $0.5 \mathrm{mg} / \mathrm{kg}$, did not influence the basal locomotor activity of mice $[F(1,60)=$ $1.059, p=0.3238]$. MGS0039, at a dose of $3 \mathrm{mg} / \mathrm{kg}$, similar to the previous experiment, did not induce significant
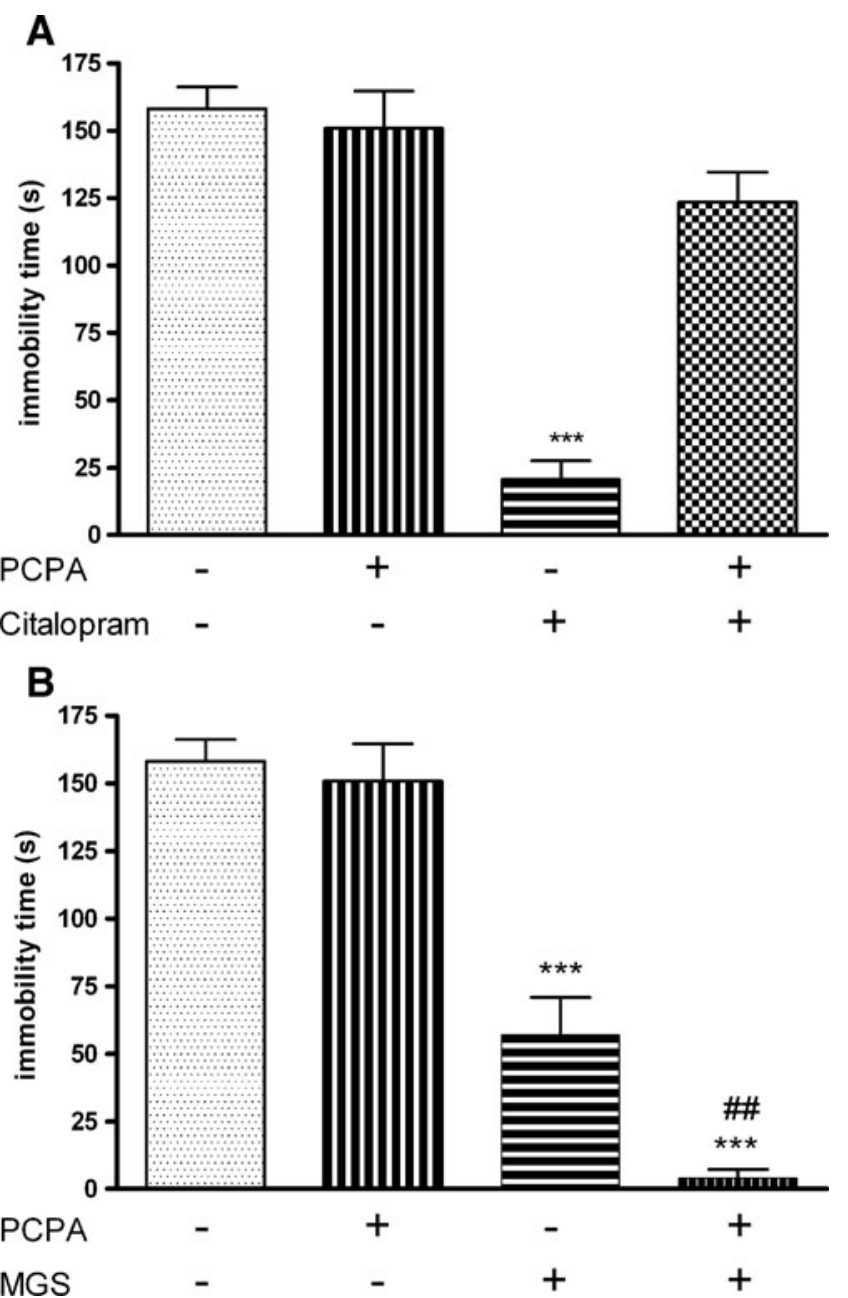

Fig. 6 The effects of serotonin depletion on the antidepressant-like activity of citalopram (Fig. 7a) or MGS0039 (Fig. 7b) in the TST in mice. Values are expressed as the means \pm SEM and analyzed by twoway ANOVA followed by Bonferroni's post hoc test. ${ }^{* * *} p<0.001$ vs. vehicle + vehicle-treated group, $\# \# p<0.001$ vs. MGS0039-treated group. Seven to eight animals per group were used 


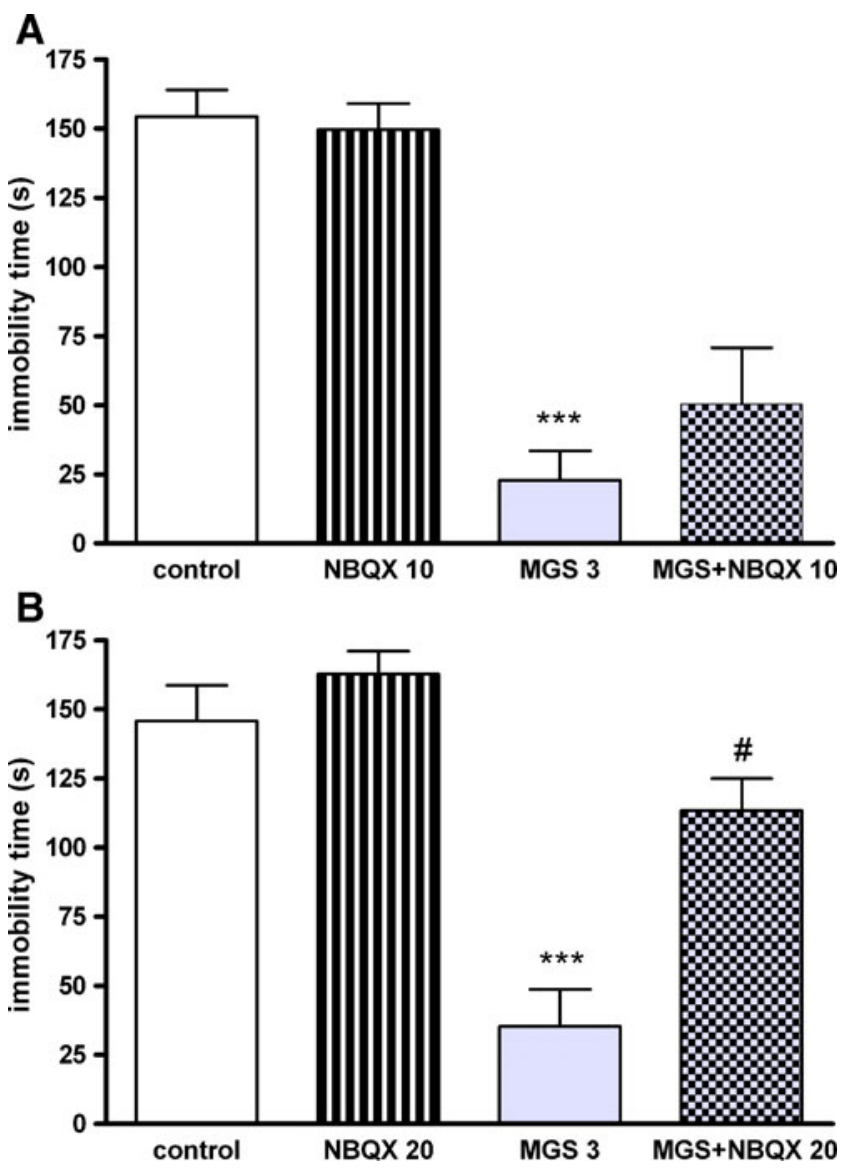

Fig. 7 The effects of AMPA receptor antagonist, NBQX $(10 \mathrm{mg} / \mathrm{kg})$ (Fig. 8a) or NBQX $(20 \mathrm{mg} / \mathrm{kg}$ ) (Fig. $8 \mathrm{~b})$ on the antidepressant-like activity of MGS0039 (3 mg/kg) in serotonin-depleted mice in the TST. Values are expressed as the means \pm SEM and analyzed by two-way ANOVA followed by Bonferroni's post hoc test. ${ }^{* * *} p<0.001$ vs. vehicle+vehicle-treated group, $\# p<0.05$ vs. MGS0039-treated group. Seven to eight animals per group were used

changes in the locomotor activity of the animals. However, locomotor activity of the mice administered with ritanserin and MGS0039 was significantly decreased, compared to the control group $[F(1,60)=10.46, p=0.0072]$. Post hoc analysis revealed that MGS0039+WAY100635 did not decrease basal locomotor activity at first two time points of 5 and $10 \mathrm{~min}(p<0.05)$, suggesting that exploratory activity was not changed $(p>0.05)$ (Fig. 8c).

The effect of the AMPA receptor antagonist and MGS0039 on the locomotor activity of mice

NBQX, given at a dose of $10 \mathrm{mg} / \mathrm{kg}$, did not induce any changes in the locomotor activity of mice $[F(1,60)=$ $0.0003507, p=0.98]$. MGS0039 $(3 \mathrm{mg} / \mathrm{kg})$, given alone or in combination with NBQX, did not influence the locomotor activity of mice $[F(1,60)=3.374, p=0.0911]$ (Fig. 8d).
Effect of citalopram and MGS0039 on the locomotor activity of both 5HT-depleted and control mice

Citalopram, given at a dose of $20 \mathrm{mg} / \mathrm{kg}$, did not influence the locomotor activity of vehicle-treated mice $[F(1,60)=$ 1.127, $p=0.3093]$. PCPA-pretreated animals were less active in the locomotor activity test than vehiclepretreated mice (the curves were significantly different) $[F$ $(1,60)=9.428, p=0.0097]$. A similar effect was observed in mice administered with citalopram, i.e., the locomotor activity of PCPA-pretreated mice was decreased when compared to vehicle-pretreated animals $[F(1,60)=15.90$, $p=0.0018$ ] (Fig. 9a).

MGS0039, administered at a dose of $3 \mathrm{mg} / \mathrm{kg}$, did not change the locomotor activity of vehicle-pretreated mice $[F$ $(1,60)=0.2948, p=0.5971]$. However, in PCPA-pretreated animals, MGS0039 induced a significant increase in the locomotor activity of mice $[F(1,60)=16.98, p=0.0014]$ (Fig. 9b).

\section{Discussion}

The aim of the present study was to investigate the potential antidepressant-like activity of a group II mGlu receptor antagonist, MGS0039, in the OB model of depression in rats and to assess the mechanism of antidepressant-like activity in the TST in C57BL/6 $\mathrm{J}$ mice.

A surgical lesion of the olfactory bulbs in animals induces significant behavioral, physiological, endocrine and immune changes, many of which were qualitatively similar to those observed in depressive patients (for review see Kelly et al. 1997). In animal studies, a variety of OB-related behavioral changes, including hyperactivity in the "open field" and deficiency in passive avoidance, responded selectively to antidepressant treatment. Hyperactivity in the "open field" always responds to chronic treatment with antidepressants, mimicking the clinical lag-time of currently used antidepressant drugs (Harkin et al. 2003). We used both tests to evaluate a potential antidepressant-like effect of MGS0039 in the OB model of depression in rats. Repeated administration of MGS0039 attenuated the hyperactivity of $\mathrm{OB}$ rats in the open field test and attenuated the learning deficit in the passive avoidance experiment, in the manner similar to that seen following chronic treatment with a typical antidepressant, amitriptyline, which was used for positive control. We also found that the administration of group II mGlu receptor antagonist did not result in any behavioral changes in the shamoperated groups, indicating that its effect in $\mathrm{OB}$ rats was not due to a stimulant or sedative effect of that compound. MGS0039-induced changes in the behavior of OB rats may be additional evidence for the support of antidepressant-like 

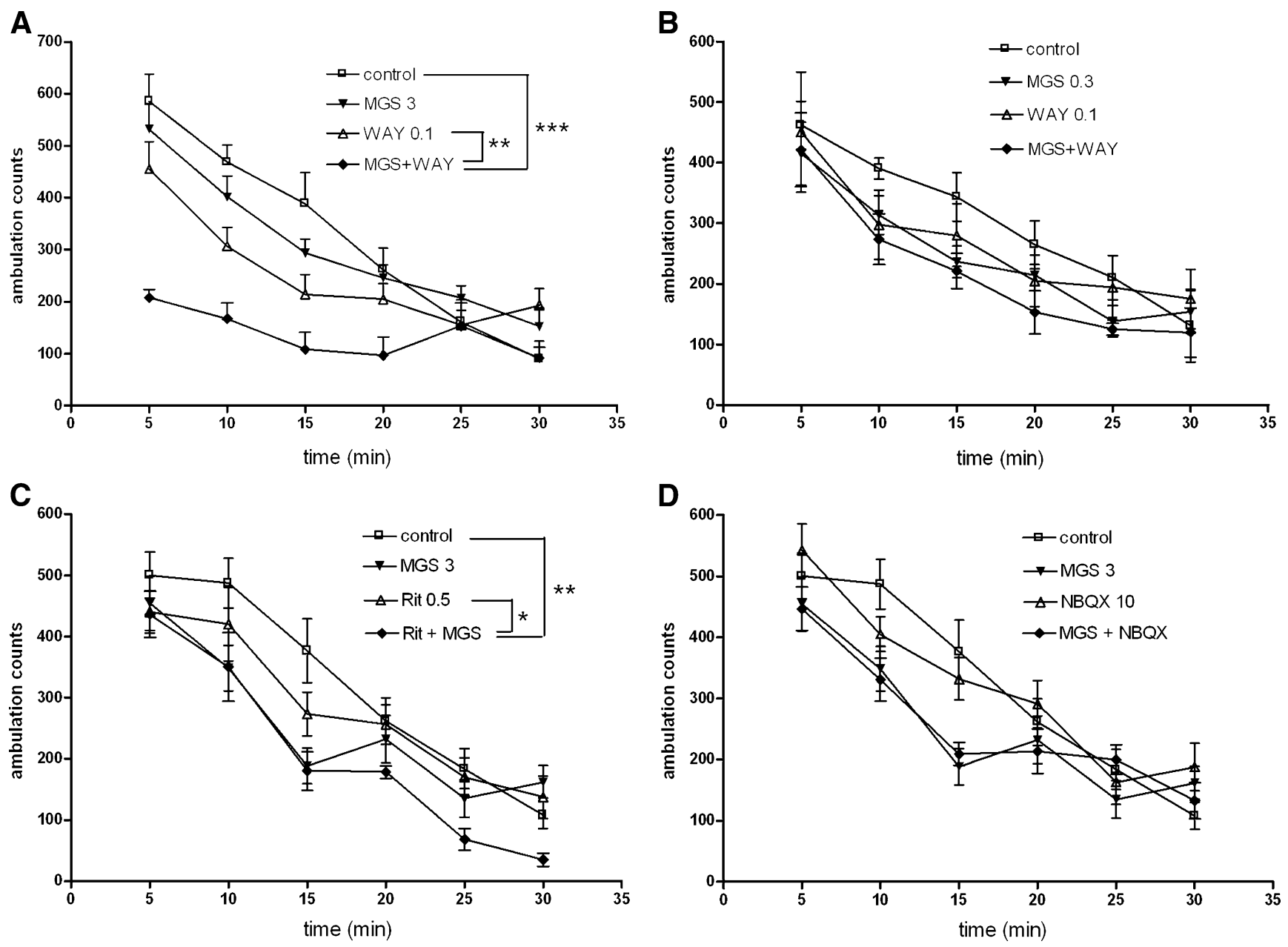

Fig. 8 a The effect of WAY100635 $(0.1 \mathrm{mg} / \mathrm{kg})$ on the locomotor activity of MGS0039 (3 mg/kg) in mice. WAY100635 and MGS0039 were administered, respectively, 45 and 30 min before the test. Values expressed as the means \pm SEM were evaluated by repeated measure ANOVA. ${ }^{* *} p<0.01$ vs. WAY100635-treated group and $* * * p<0.001$ vs. control group (Dunnett's test). b The effect of WAY 100635 $(0.1 \mathrm{mg} / \mathrm{kg})$ on the locomotor activity of MGS0039 $(0.3 \mathrm{mg} / \mathrm{kg})$ in mice. WAY100635 and MGS0039 were administered, respectively, 45 and $30 \mathrm{~min}$ before the test. Values expressed as the means \pm SEM were evaluated by repeated measure ANOVA. c The effect of

activity of group II mGlu receptor antagonists. However, it must be remembered, that agonists of group II mGlu receptors were shown to produce a number of desirable effects, such as anti-seizures, neuroprotective, and antipsychotic effects (Conn et al. 2009; Flor et al. 2002; Klodzinska et al. 2000; Ure et al. 2006). As such, the application of antagonists of mGlu $2 / 3$ receptors may carry a risk of undesirable side effects and must be further investigated.

To investigate the mechanism of the antidepressant-like activity of MGS0039, the TST was chosen in this study, since it is widely used to determine behavioral effects of typical antidepressant drugs influencing the serotonergic,

ritanserin $(0.5 \mathrm{mg} / \mathrm{kg})$ on the locomotor activity of MGS0039 (3 mg/ $\mathrm{kg}$ ) in mice. Ritanserin and MGS0039 were administered, respectively, 60 and $30 \mathrm{~min}$ before the test. Values expressed as the means \pm SEM were evaluated by repeated measure ANOVA. ${ }^{*} p<0.05$ vs. ritanserin-treated group and $* * p<0.01$ vs. control group (Dunnett's test). d The effect of NBQX $(10 \mathrm{mg} / \mathrm{kg})$ on the locomotor activity of MGS0039 (3 mg/kg) in mice. NBQX and MGS0039 were administered, respectively, 35 and $30 \mathrm{~min}$ before the test. Values expressed as the means \pm SEM were evaluated by repeated measure ANOVA. Six animals per group were used

noradrenergic, and dopaminergic systems, as well as atypical and new potential antidepressants, including mGlu receptor ligands (Cryan et al. 2005). Here, we observed the antidepressant-like activity of MGS0039 and another group II mGlu receptor antagonist LY341495, after peripheral administration in the TST in mice. Although the potential antidepressant-like activity of group II mGlu receptor antagonists seems to be well established, the mechanism by which these compounds exhibit such effects is still unclear. However, some data indicates that it may be related to serotonergic system regulation (see "Introduction"), thus resembling the mechanism of action of typical antidepressants such as SSRIs. 

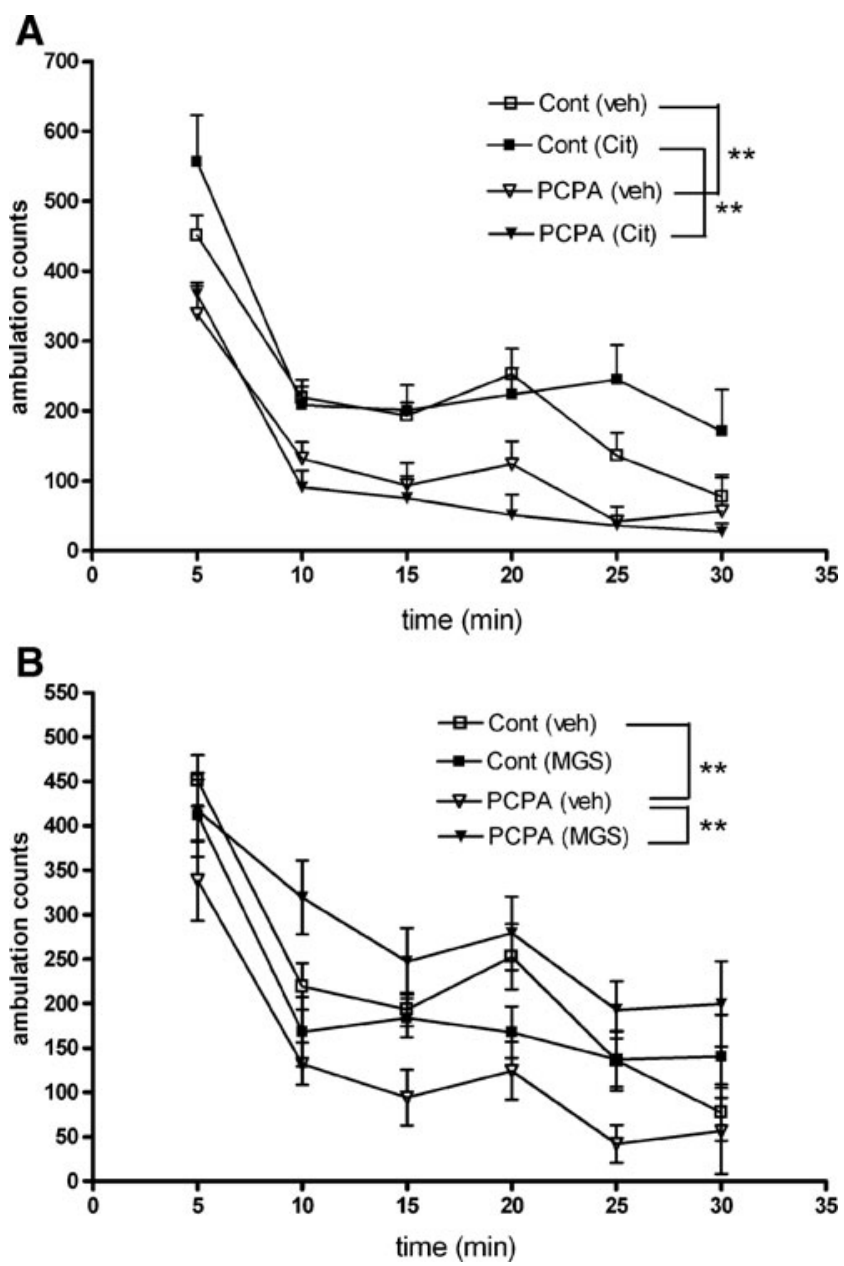

Fig. 9 The effects of citalopram (a) and MGS0039 (b) on the locomotor activity of serotonin-depleted and control mice. Values expressed as the means \pm SEM were evaluated by repeated measure ANOVA, ${ }^{* *} p<0.01$ vs. respective control group (Dunnett's test). Seven animals per group were used

Therefore, we aimed to clarify the role of the serotonergic system in the antidepressant-like action of mGlu2/3 receptor antagonists in the TST. Firstly, we investigated the influence of the pretreatment of mice with specific serotonergic receptors antagonists, such as the 5HT1A receptor antagonist, WAY100635 (Forster et al. 1995), and $5 \mathrm{HT} 2 \mathrm{~A} / 2 \mathrm{C}$ receptor antagonist, ritanserin (Hoyer et al. 1994), on the antidepressant-like activity of MGS0039 or LY341495 in the TST. Secondly, an influence of MGS0039 on the immobility time in the TST was measured in C57BL/ $6 \mathrm{~J}$ mice after the pharmacological depletion of serotonin.

Several lines of evidence indicate the crucial role of both 5HT1A and 5HT2A receptors in the regulation of serotonergic neurotransmission and the involvement of these receptors in the mechanism of action of many classes of antidepressant drugs, including SSRI, MAOI, and tricyclics (Hensler 2002; Middlemiss et al. 2002). It was also shown that pretreatment with antagonists of 5HT1A and 5HT2A receptors antagonized antidepressant-like activity of SSRIs in the TST in mice (Miyata et al. 2004), suggesting that activation of both receptors plays a key role in the action of compounds acting via activation of the serotonergic system in this test. The results of our studies show that pretreatment of mice with WAY 100635 or ritanserin did not influence an antidepressant-like action of MGS0039 in the TST. Similarly, the antidepressant-like activity of another group II mGlu receptor antagonist, LY341495, was not changed in mice pretreated with WAY100635 or ritanserin. Furthermore, the antidepressant-like activity of LY341495 was not blocked by metergoline, which is an antagonist of a wide spectrum of serotonergic receptors, including 5HT1, 5HT2, 5HT1D, 5HT6, and 5HT7 (Hoyer et al. 1994). These results suggest that activation of the serotonergic system is not required in the antidepressant-like action of group II mGlu receptor antagonists.

It has been shown that 5HT1A antagonists enhance antidepressant-like activity of antidepressants acting via the activation of the serotonergic system, when given at low, sub-effective doses (Artigas et al. 1996). This effect resulted probably from a blockade of 5HT1A autoreceptors by $5 \mathrm{HT} 1 \mathrm{~A}$ antagonists and a subsequent increase in the level of serotonin. Thus, the antagonists of 5HT1A receptors synergistically potentiate the serotonin level, increased by SSRIs (Romero et al. 1996). Our study shows that the action of the group II mGlu receptors antagonist, MGS0039, was not significantly potentiated by an antagonist of the 5HT1A receptor, WAY100635, further confirming that the mechanism of the antidepressant-like activity of MGS0039 was not serotonin-dependent.

Locomotor activity studies showed that MGS0039, WAY100635, or ritanserin given by themselves did not change this parameter in mice, confirming that the antidepressant-like action of MGS0039 was not due to hyperlocomotion. However, in mice pretreated with WAY100635 or ritanserin, MGS0039 significantly diminished locomotor activity, suggesting that the lack of influence of serotonergic blockers on the action of MGS0039 in the TST was not a false negative effect resulting from their influence on the hyperlocomotion. On the other hand, our locomotor activity results suggest the existence of interaction between group II mGlu receptors and serotonin 5HT1A and 5HT2A receptors. Functional and structural interaction between mGlu2 and 5HT2A receptors is well documented, and it is believed to be implicated in psychosis (González-Maeso et al. 2008; Kłodzińska et al. 2002; Marek et al. 2000). Moreover, the anxiolytic-like activity of mGlu receptor ligands was shown to be dependent on the activation of the serotonergic receptors; e.g., the anxiolytic-like action of mGlu5 receptor antagonist, MTEP, or group III mGlu receptor antagonist, 
CPPG, were blocked by $5 \mathrm{HT} 2 \mathrm{~A} / 2 \mathrm{C}$ receptor antagonist, ritanserin, while group III mGlu receptor agonist, ACPT-I, did not display anxiolytic-like activity in mice pretreated with 5HT1A receptor antagonist, WAY100635 (Stachowicz et al. 2007a, 2007b, 2009), suggesting a functional interaction between group I or III mGlu receptors and serotonergic 5HT1A and 5HT2A/2C receptors in anxietyrelated mechanisms. Although our locomotor activity results indicate on interaction between group II mGlu receptors and $5 \mathrm{HT} 1 \mathrm{~A}$ or $5 \mathrm{HT} 2 \mathrm{~A} / 2 \mathrm{C}$ receptors, it seems that this interaction did not play a role in the antidepressantlike activity of the glutamatergic and serotonergic antagonists tested in the TST.

It is worth mentioning that our results, showing no changes in the locomotor activity of mice after administration of group II mGlu receptor antagonists, seem to be opposite to other studies where it was reported that the group II mGlu receptor antagonist LY341495 increased the locomotor activity of mice (Bespalov et al. 2007; O'Neill et al. 2003). However, in these studies, an influence of the compound on the locomotor activity of habituated animals was investigated. In our studies, animals were given an injection of MGS0039 in a home cage, and $30 \mathrm{~min}$ later, they were put into actometers before the locomotor activity was measured. This paradigm showed an influence of tested compounds on spontaneous locomotor activity in a new environment, and the treatment schedule was adequate to that used in the TST, where animals were given an MGS0039 injection, and after $30 \mathrm{~min}$, they were hung for $5 \mathrm{~min}$ by their tails.

In order to further investigate the role of serotonin in the mechanism of the antidepressant-like activity of group II mGlu receptor antagonists, we used PCPA to achieve 5HT depletion. PCPA is a selective inhibitor of tryptophan hydroxylase (Koe and Weissman 1966) and has been shown to decrease the brain 5HT level by about $78 \%$, after IP administration, at a dose of $300 \mathrm{mg} / \mathrm{kg}$, twice daily, for three consecutive days (O'Leary et al. 2007). This schedule for the administration of PCPA was used to investigate the role of serotonin in the antidepressant activity of SSRIs in the TST in C57BL mice (O'Leary et al. 2007). The results have clearly shown that citalopram and fluoxetine were not active in the serotonin-depleted mice, while in control groups of animals (not treated with PCPA), both compounds induced a significant decrease in the immobility time in the TST. Thus, in our study, we used the same scheme of PCPA administration. We confirmed that citalopram induced a significant antidepressant effect in vehicle-treated mice, decreasing the immobility time. However, in a group of animals administered with PCPA, citalopram did not change the immobility time of mice compared to that of a respective control group, confirming that PCPA-induced 5HT depletion was enough to inhibit the behavioral effect of a compound selectively acting via serotonergic system modulation. The profile of the action of MGS0039 was therefore opposite to that of citalopram; its antidepressantlike activity in serotonin-depleted animals was not inhibited but significantly enhanced.

We also examined an influence of MGS0039 on locomotor activity. The results clearly show that while MGS0039, in a dose of $3 \mathrm{mg} / \mathrm{kg}$, did not change the locomotor activity of vehicle-treated mice, it induced a significant hyperlocomotion of serotonin-depleted animals in the 30-min test, although it remained without a significant influence during the first $5 \mathrm{~min}$ of the locomotor activity test, i.e., the time adequate for the duration of the TST. Thus, the hyperlocomotion induced by MGS0039 in PCPA-pretreated mice seems not to be the reason for the decreased immobility of mice in the tail suspension test.

Our studies confirm the observation of Karasawa et al. 2005 that the antidepressant-like activity of MGS0039 was dependent on AMPA receptor activation, as AMPA receptor antagonist, NBQX, given at a dose of $10 \mathrm{mg} / \mathrm{kg}$, prevented its antidepressant-like activity in the TST. Interestingly, a higher dose $(20 \mathrm{mg} / \mathrm{kg})$ of NBQX was necessary to block the antidepressant-like activity of MGS0039 in PCPAtreated mice. It can be speculated that an increased level of AMPA receptors in PCPA-treated animals accounted for the lesser ability of NBQX to block the antidepressant-like effect induced by MGS0039 in PCPA-pretreated mice, which may confirm the data of Shutoh et al. (2000) showing an increased level of AMPA receptors in PCPAtreated animals. Also, enhanced activity of MGS0039 in the PCPA-pretreated mice is not specifically antidepressant like it seems, but rather a false positive effect, resulting probably from changes in AMPA receptor level.

Altogether, the results of our studies show that MGS0039 was active in the OB model of depression, suggesting that the prolonged blockade of mGlu2/3 receptor may be effective in the treatment of depression. Furthermore, the results of our TST studies show that the antidepressant-like action of group II mGlu receptor antagonists does not depend on serotonergic system activation, indicating that the mechanism of the action of group II mGlu receptor antagonists differs from that of typical antidepressants, such as SSRIs. Moreover, we conclude that the AMPA receptor seems to play a key role in the antidepressant-like action of these compounds.

Acknowledgements This work was supported by Funds for Statutory Activity of the Institute of Pharmacology Polish Academy of Sciences and by Grant of Ministry of Science and Higher Education no. NN405 055737. 
Open Access This article is distributed under the terms of the Creative Commons Attribution Noncommercial License which permits any noncommercial use, distribution, and reproduction in any medium, provided the original author(s) and source are credited.

\section{References}

Artigas F, Romero L, de Montigny C, Blier P (1996) Acceleration of the effect of selected antidepressant drugs in major depression by 5-HT1A antagonists. Trends Neurosci 19:378-383

Bespalov A, Jongen-Rêlo AL, van Gaalen M, Harich S, Schoemaker H, Gross G (2007) Habituation deficits induced by metabotropic glutamate receptors $2 / 3$ receptor blockade in mice: reversal by antipsychotic drugs. J Pharmacol Exp Ther 320:944-950

Chaki R, Yoshikawa S, Hirota T, Shimazaki M, Maeda KN, Yoshimizu T, Yasuhara A, Sakagami K, Okuyama S, Nakanishi S, Nakazato A (2004) MGS0039: a potent and selective group II metabotropic glutamate receptor antagonist with antidepressantlike activity. Neuropharmacology 46:457-467

Conn PJ, Pin JP (1997) Pharmacology and functions of metabotropic glutamate receptors. Annu Rev Pharmacol Toxicol 37:205-237

Conn PJ, Lindsley CW, Jones CK (2009) Activation of metabotropic glutamate receptors as a novel approach for the treatment of schizophrenia. Trends Pharmacol Sci 30:25-31

Cryan JF, Mombereau C, Vassout A (2005) The tail suspension test as a model for assessing antidepressant activity: review of pharmacological and genetic studies in mice. Neurosci Biobehav Rev 29:571-625

Detke MJ, Rickels M, Lucki I (1995) Active behaviors in the rat forced swimming test differentially produced by serotonergic and noradrenergic antidepressants. Psychopharmacology (Berl) 121:66-72

Flor PJ, Battaglia G, Nicoletti F, Gasparini F, Bruno V (2002) Neuroprotective activity of metabotropic glutamate receptor ligands. Adv Exp Med Biol 513:197-223

Forster EA, Cliffe LA, Bill DJ, Dover GM, Jones D, Reilly Y, Flether A (1995) A pharmacological profile of the selective silent 5HT1A receptor antagonist WAY 100635. Eur J Pharmacol 281:81-88

González-Maeso J, Ang RL, Yuen T, Chan P, Weisstaub NV, LópezGiménez JF, Zhou M, Okawa Y, Callado LF, Milligan G, Gingrich JA, Filizola M, Meana JJ, Sealfon SC (2008) Identification of a serotonin/glutamate receptor complex implicated in psychosis. Nature 452:93-97

Harkin A, Kelly JP, Leonard BE (2003) A review of the relevance and validity of olfactory bulbectomy as a model of depression. Clin Neurosci Res 3:253-262

Hensler JG (2002) Regulation of 5-HT1A receptor function in brain following agonist or antidepressant administration. Life Sci $72: 1665-1682$

Hoyer D, Clarke DE, Fozard JR, Hartig PR, Martin GR, Mylecharane EJ, Saxena PR, Humphrey PPA (1994) VII. International union of pharmacology classification of receptors for 5hydroxytryptamine (serotonin). Pharmacol Rev 46:157-203

Karasawa J, Shimazaki T, Kawashima N, Chaki S (2005) AMPA receptor stimulation mediates the antidepressant-like effect of a group II metabotropic glutamate receptor antagonist. Brain Res 1042:92-98

Kawashima N, Karasawa J, Shimazaki T, Chaki S, Okuyama S, Yasuhara A, Nakazato A (2005) Neuropharmacological profiles of antagonists of group II metabotropic glutamate receptors. Neurosci Lett 378:131-134

Kelly JP, Wrynn AS, Leonard BE (1997) The olfactory bulbectomized rat as a model of depression: an update. Pharmacol Ther 74:299-316
Klodzinska A, Bijak M, Chojnacka-Wojcik E, Kroczka B, Swiader M, Czuczwar SJ, Pilc A (2000) Roles of group II metabotropic glutamate receptors in modulation of seizure activity. NaunynSchmied Arch Pharmacol 361:283-288

Kłodzińska A, Tokarski K, Bijak M, Pilc A (2002) Group II mGlu receptor agonists inhibit behavioural and electrophysiological effects of DOI in mice. Pharmacol Biochem Behav 73:327332

Koe BK, Weissman A (1966) P-Chlorophenylalanine: a specific depletory of brain serotonin. J Pharmacol Exp Ther 154:499-516

Leonard BE, Tuite M (1981) Anatomical, physiological, and behavioral aspects of olfactory bulbectomy in the rat. Int Rev Neurobiol 22:251-286

Marek GJ, Wright RA, Schoepp DD, Monn JA, Aghajanian GK (2000) Physiological antagonism between 5-hydroxytryptamine (2A) and group II metabotropic glutamate receptors in prefrontal cortex. J Pharmacol Exp Ther 292:76-87

Middlemiss DN, Price GW, Watson JM (2002) Serotonergic targets in depression. Curr Opin Pharmacol 2:18-22

Miyata S, Hirano S, Kamei J (2004) Diabetes attenuates the antidepressant-like effect mediated by the activation of 5-HT1A receptor in the mouse tail suspension test. Neuropsychopharmacology 29:461-469

Nowak G, Partyka A, Pałucha A, Szewczyk B, Wierońska JM, Dybała M, Metz M, Librowski T, Froestl W, Papp M, Pilc A (2006) Antidepressant-like activity of CGP 36742 and CGP 51176, selective GABAB receptor antagonists, in rodents. Br J Pharmacol 149:581-590

O'Leary OF, Bechtholt AJ, Crowley JJ, Hill TE, Page ME, Lucki I (2007) Depletion of serotonin and catecholamines block the acute behavioral response to different classes of antidepressant drugs in the mouse tail suspension test. Psychopharmacology (Berl) 192:357-371

O'Neill MF, Heron-Maxwell C, Conway MW, Monn JA, Ornstein P (2003) Group II metabotropic glutamate receptor antagonists LY341495 and LY366457 increase locomotor activity in mice. Neuropharmacology 45:565-574

Ornstein PL, Arnold MB, Bleisch TJ, Wright RA, Wheeler WJ, Schoepp DD (1998) [3H]LY341495, a highly potent, selective and novel radioligand for labeling group II metabotropic glutamate receptors. Bioorg Med Chem Lett 8:1919-1922

Pałucha A, Brański P, Szewczyk B, Wierońska JM, Kłak K, Pilc A (2005) Potential antidepressant-like effect of MTEP, a potent and highly selective mGluR5 antagonist. Pharmacol Biochem Behav 81:901-906

Pałucha A, Pilc A (2007) Metabotropic glutamate receptor ligands as possible anxiolytic and antidepressant drugs. Pharmacol Ther 115:116-147

Pilc A, Kłodzińska A, Brański P, Nowak G, Pałucha A, Szewczyk B, Tatarczyńska E, Chojnacka-Wójcik E, Wierońska JM (2002) Multiple MPEP administrations evoke anxiolytic- and antidepressant-like effects in rats. Neuropharmacology 43:181187

Pilc A, Chaki S, Nowak G, Witkin JM (2008) Mood disorders: regulation by metabotropic glutamate receptors. Biochem Pharmacol 75:997-1006

Redmond AM, Kelly JP, Leonard BE (1997) Behavioural and neurochemical effects of dizocilpine in the olfactory bulbectomized rat model of depression. Pharmacol Biochem Behav 58:355359

Romero L, Hervás I, Artigas F (1996) The 5-HT1A antagonist WAY100635 selectively potentiates the presynaptic effects of serotonergic antidepressants in rat brain. Neurosci Lett 219:123-126

Santarelli L, Saxe M, Gross C, Surget A, Battaglia F, Dulawa S, Weisstaub N, Lee J, Duman R, Arancio O, Belzung C, Hen R 
(2003) Requirement of hippocampal neurogenesis for the behavioral effects of antidepressants. Science 301:805-809

Shutoh F, Hamada S, Shibata M, Narita M, Shiga T, Azmitia EC, Okado N (2000) Long term depletion of serotonin leads to selective changes in glutamate receptor subunits. Neurosci Res 38:365-371

Skolnick P, Popik P, Trullas R (2009) Glutamate-based antidepressants: 20 years on. Trends Pharmacol Sci 30:563-569

Stachowicz K, Chojnacka-Wójcik E, Kłak K, Pilc A (2007a) Anxiolytic-like effect of group III mGlu receptor antagonist is serotonin-dependent. Neuropharmacology 52:306-312

Stachowicz K, Gołembiowska K, Sowa M, Nowak G, ChojnackaWójcik E, Pilc A (2007b) Anxiolytic-like action of MTEP expressed in the conflict drinking Vogel test in rats is serotonin dependent. Neuropharmacology 53:741-748

Stachowicz K, Kłodzińska A, Pałucha-Poniewiera A, Schann S, Neuville P, Pilc A (2009) The group III mGlu receptor agonist ACPT-I exerts anxiolytic-like but not antidepressant-like effects, mediated by the serotonergic and GABA-ergic systems. Neuropharmacology 57:227-234
Steru L, Chermat R, Thierry B, Simon P (1985) Tail suspension test: a new method for screening antidepressants in mice. Psychopharmacology (Berl) 85:367-370

Ure J, Baudry M, Perassolo M (2006) Metabotropic glutamate receptors and epilepsy. J Neurol Sci 247:1-9

Wierońska JM, Pilc A (2009) Metabotropic glutamate receptors in the tripartite synapse as a target for new psychotropic drugs. Neurochem Int 55:85-97

Wierońska JM, Szewczyk B, Brański P, Pałucha A, Pilc A (2002) Antidepressant-like effect of MPEP, a potent, selective and systemically active mGlu5 receptor antagonist in the olfactory bulbectomized rats. Amino Acids 23:213-216

Yoshimizu T, Chaki S (2004) Increased cell proliferation in the adult mouse hippocampus following chronic administration of group II metabotropic glutamate receptor antagonist, MGS0039. Biochem Biophys Res Commun 315:493-496

Yoshimizu T, Shimazaki T, Ito A, Chaki S (2006) An mGluR2/3 antagonist, MGS0039, exerts antidepressant and anxiolytic effects in behavioral models in rats. Psychopharmacology 186:587-593 